\title{
TANGGUNG JAWAB HUKUM CALON NOTARIS YANG SEDANG MAGANG TERHADAP KERAHASIAAN AKTA
}

\author{
Rani Yuliani ${ }^{1}$ \\ Fakultas Hukum Magister Kenotariatan \\ Universitas Narotama Surabaya \\ E-mail : ranidedi369@gmail.com
}

\begin{abstract}
ABSTRAK
Magang merupakan syarat mutlak bagi calon notaris menjadi seorang Notaris, Calon notaris melakukan magang yaitu di kantor Notaris, kantor Notaris yang menerima magang tentu sedikit banyak rahasia aktanya akan diketahui oleh calon notaris yang magang. Tesis ini ingin menelaah dan menganalisa lebih lanjut tentang tanggung jawab calon notaris yang sedang magang dalam merahasiakan akta dan bentuk-bentuk sanksi bagi calon notaris yang sedang magang yang membocorkan rahasia akta. Penelitian hukum normatif, Hasil penelitian menunjukkan bahwa calon notaris yang melaksanakan magang dalam suatu kantor Notaris berkewajiban menjaga rahasia akta dan segala keterangan yang diperoleh dalam pembuatan akta hal tersebut berdasarkan pada Pasal 16 A ayat 2 UUJN, pelaksanaan atas isi pasal tersebut merupakan bentuk dari tanggung jawab calon notaris kepada negara, dalam hal calon notaris membocorkan rahasia akta, maka dapat dikenai sanksi secara pidana yaitu sebagaimana diatur dalam Pasal 85 Undang-Undang Nomor 43 Tahun 2009 Tentang Kearsipan juncto Pasal 54 ayat (1) Undang-Undang Nomor 14 Tahun 2008 Tentang Keterbukaan Informasi Publik serta sanksi secara perdata sesuai Pasal 1365 KUHPerdata.
\end{abstract}

Kata Kunci : Calon Notaris, Tanggung Jawab, Sanksi

\footnotetext{
${ }^{1}$ Mahasiswa Fakutas Hukum Narotama
} 


\section{A. PENDAHULUAN}

Indonesia sebagai negara hukum (rechtstaat) sebagaimana telah dituangkan dalam Pasal 1 ayat (3) Undang-Undang Dasar Negara Republik Indonesia Tahun 1945 (selanjutnya disebut UUD 1945) mengharuskan bahwa setiap kekuasaan didalam suatu negara harus berdasarkan atas hukum.Prinsip negara hukum menjamin kepastian, ketertiban dan perlindungan hukum yang berintikan kebenaran dan keadilan. ${ }^{2}$ Ismail Suny dalam brosur beliau "Mekanisme Demokrasi Pancasila" mengatakan, bahwa negara hukum Indonesia memuat unsur-unsur $:^{3}$

1. Menjunjung tinggi hukum;

2. Adanya pembagian kekuasaan;

3. Adanya perlindungan terhadap hak-hak asasi manusia serta remedi-remedi prosedural untuk mempertahankannya;

4. Dimungkinkan adanya peradilan administrasi.

Jabatan Notaris diadakan atau kehadirannya dikehendaki oleh aturan hukum dengan maksud untuk membantu

${ }^{2}$ Supriadi, Etika \& Tanggung Jawab Profesi Hukum di Indonesia, Sinar Grafika, Jakarta, 2008, h. 29

${ }^{3}$ C.S.T Kansil dan Christine S. T. Kansil, Hukum Tata Negara Republik Indonesia, Rineka Cipta, Jakarta, 2008, h. 87 dan melayani masyarakat yang membutuhkan alat bukti tertulis yang bersifat otentik megenai keadaan, peristiwa atau perbuatan hukum. ${ }^{4}$ Notaris tidak berarti apa-apa jika masyarakat tidak membutuhkannya. Dalam kaitannya menjadi seorang notaris yang mempunyai dedikasi dan integritas dalam menajalankan jabatannya tentu harus sudah dibentuk moral serta akhlaknya sejak dilahirkan, namun secara khusus, moral dan akhlak sebagai notaris harus dibentuk sejak ia mengikuti masa perkuliahan pasca sarjana magister kenotariatan.

Sebelum terbitnya Undang-Undang No. 30 Tahun 2004 tentang Jabatan Notaris yang sekarang telah diubah dengan Undang-Undang No. 2 Tahun 2014 tentang Perubahan Atas Undang-Undang No. 30 Tahun 2004 tentang Jabatan Notaris atau yang lebih dikenal dengan UUJN, peraturan yang digunakan untuk mengatur mengenai jabatan notaris adalah Staadblad No.3 Tahun 1860. Peraturan yang disebut terakhir merupakan salah satu produk perundang-undangan yang ditetapkan oleh Gubernur Jenderal Nederlands Indie, jadi

\footnotetext{
${ }^{4}$ Habib Adjie, Hukum Notaris IndonesiaTafsir Tematik Terhadap UU No. 30 Tahun 2004 Tentang Jabatan Notaris, Refika Aditama, Bandung, 2008, h. 14
} 
merupakan ordonansi tanggal 11 Januari 1860.

Seiring berjalannya waktu, Menteri Kehakiman sebagai institusi yang paling bertanggung jawab atas pengangkatan notaris, mengeluarkan keputusan No.M-OL.H.T.03.01 Tahun 2003 tentang Kenotarisan. Di dalam keputusan tersebut diatur mengenai pengangkatan notaris bahwa untuk dapat diangkat menjadi notaris, calon notaris mengajukan permohonan dengan memenuhi beberapa syarat yang lebih detail daripada syarat yang ditentukan di dalam Stbl 1860 No. 3. adapun syarat-syarat yang harus dipenuhi yaitu:

a. Warga Negara Indonesia;

b. Bertaqwa kepada Tuhan Yang Maha Esa;

c. Setia kepada Pancasia dan UUD 1945

d. Berkelakuan baik yang dinyatakan dengan surat keterangan dari Kepolisian

Negara Republik Indonesia;

e. Lulus pendidikan spesialis notariat atau Magister kenotariatan yang diselenggarakan perguruan tinggi negeri;

f. Telah mengikuti pelatihan teknis yang diselenggarakan Direktorat Jenderal
Administrasi Umum

Departemen

Kehakiman dan Hak Asasi Manusia

Republik Indonesia;

g. Berumur serendah-rendahnya 25 (dua puluh lima) tahun;

h. Sehat jasmani dan rohani.

Memang, mengenai persyaratan "masa magang" tidak dimasukkan secara langsung, tetapi menjadi persyaratan formal dengan melampirkan surat keterangan dari Notaris bahwa telah mengikuti magang di kantor Notaris selama dua tahun berturut-turut setelah lulus pendidikan spesialis notariat atau magister kenotariatan yang disahkan oleh organisasi setempat. Dengan adanya keputusan dari Menteri Kehakiman tersebut, maka "surat keterangan telah mengikuti magang" bagi calon notaris merupakan keharusan sebagai syarat formal dalam pengajuan permohonan pengangkatan, bukan "magang"nya.

Namun ada beberapa kekhawatiran yang dihadapi oleh para calon notaris yang akan melaksanakan magang, yaitu adanya penolakan oleh Notaris terhadap calon notaris yang akan melaksanakan magang di kantonya walaupun terdapat kewajiban bagi Notaris untuk menerima magang calon notaris sebagaimana tertuang dalam Pasal 16 ayat (1) huruf n Undang-Undang Jabatan Notaris Nomor 2 Tahun 2014, hal 
ini diakibatkan oleh beberapa perbuatan atau perilaku calon notaris yang sedang magang yang merugikan kantor dimana calon notaris tersebut melakukan magang, sehingga sebagian notaris memilih tidak menerima magang bagi calon notaris, tentu hal tersebut akan menghambat terselenggaranya jabatan notaris secara berkelanjutan mengingat magang adalah syarat mutlak yang diperintahkan oleh undang-undang untuk menjadi seorang Notaris.

Selain alasan yang telah diuraikan diatas, Notaris yang menolak calon notaris magang beralasan bahwa dikhawatirkan akan kerahasiaan akta dan segala sesuatu yang berkaitan dengan kantornya akan terbuka kemasyarakat umum yang seharusnya hal tersebut merupakan rahasia, karena selama magang calon notaris tersebut secara otomatis akan mempelajari secara praktek baik mengenai pembuatan akta maupun tentang manajemen kantornya, sehingga perlu adanya regulasi yang jelas tentang pengaturan yang lebih rinci terhadap setiap tindakan atau perbuatan yang mengatur calon notaris dalam melaksanakan magang.

\section{B. METODE PENELITIAN}

Penelitian yang dilakukan adalah penelitian hukum normatif (Normative Legal Research), yaitu penelitian yang dilakukan dengan cara mengkaji peraturan perundang-undangan yang berlaku atau diterapkan terhadap suatu permasalahan tertentu. Penelitian normatif seringkali disebut dengan penelitian doktrinal, yang penelitian objek kajiannya adalah dokumen peraturan perundang-undangan dan bahan pustaka. ${ }^{5}$

Pendekatan yang digunakan dalam penelitian hukum ini adalah pendekatan perundang-undangan (statue approach) dan pendekatan konseptual (conceptual approach). Pendekatan perundang-undangan (statue approach) yaitu, "pendekatan yang dilakukan dengan menelaah semua undang-undang dan regulasi yang bersangkut paut dengan isu hukum yang sedang ditangani". 6

Sedangkan pendekatan konseptual (conceptual approach) adalah, "pendekatan yang beranjak dari pandangan-pandangan dan doktrin-doktrin yang berkembang di dalam ilmu hukum.Pemahaman akan pandangan-pandangan dan doktrin-doktrin tersebut merupakan sandaran bagi peneliti dalam membangun suatu argumentasi

\footnotetext{
5 Soejono dan H. Abdurahman, Metode Penelitian Hukum, Rineka Cipta, Jakarta, 2003, h. 56

6 Peter Mahmud Marzuki, Penelitian Hukum, Kencana Prenada Media Group, Jakarta, 2007, h. 93
} 
hukum dalam memecahkan isu yang dihadapi"? 7

\section{PEMBAHASAN}

TANGGUNG JAWAB

CALON

NOTARIS YANG

SEDANG

MAGANGTERHADAP

\section{KERAHASIAAN AKTA}

\section{Tentang Calon Notaris}

Mengingat tidak ada literatur yang menyebutkan siapa sesungguhnya calon notaris ini, penulis dapat merumuskan sendiri mengenai pengertian dari calon notaris, calon notaris adalah seseorang yang telah lulus dari program studi strata dua kenotariatan dan melakukan magang di kantor notaris, tentunya dengan terlebih dahulu mendaftarkan dirinya tersebut menjadi Anggota Luar Biasa pada organisasi notaris yaitu Ikatan Notaris Indonesia sesuai dengan pasal 82 ayat (2) Undang-Undang Jabatan Notaris Nomor 2 Tahun 2014, yaitu "Wadah Organisasi Notaris sebagaimana dimaksud pada ayat (1) adalah Ikatan Notaris Indonesia".

Lebih lanjut tentang tata cara untuk menjadi Anggota Luar Biasa kaitannya dalam pelaksanaan magang yang dipersyaratkan oleh undang-undang, telah dinyatakan dalam Pasal 4 Perubahan Anggaran Dasar Rumah Tangga Ikatan Notaris Indonesia, adalah sebagai berikut :
Syarat untuk menjadi anggota luar biasa :

a. telah lulus program studi starata dua kenotariatan atau program spesialis kenotariatan.

b. telah memiliki ijazah program studi starata dua kenotariatan atau program spesialis kenotariatan.

c. telah membayar uang pangkal.

2. Tata cara menjadi anggota luar biasa adalah dengan mengajukan permohonan kepada Pengurus Daerah ditempat kedudukannya dengan mengisi dan menyerahkan formulir yang disediakan oleh Pengurus Daerah di tempat domisilinya dengan melampirkan :

a. Fotokopi sesuai asli :

a.1. Kartu Tanda Penduduk.

a.2. Ijazah program studi starata dua kenotariatan atau program spesialis kenotariatan.

b. Pasfoto berwarna ukuran 4x6 sebanyak 2 lembar.

c. Tanda terima yang sah atas pembayaran uang pangkal.

d. Surat pernyataan untuk tunduk dan taat pada Anggaran Dasar, Anggaran Rumah Tangga, dan Kode Etik Notaris, serta peraturan lain yang telah dan yang akan ditetapkan oleh perkumpulan. 
3. Apabila di tempat kedudukan Notaris yang bersangkutan belum terbentuk Pengurus Daerah, maka surat pendaftaran diajukan kepada Pengurus Wilayah yang membawahi tempat domisili yang bersangkutan.

4. Terhitung sejak diterimanya surat pendaftaran sebagai anggota luar biasa secara lengkap, Pengurus Daerah mencatat keanggotaan luar biasa yang bersangkutan dalam Buku Daftar Anggota Luar Biasa.

5. Dalam hal Pengurus Daerah belum terbentuk sebagaimana yang dimaksud ayat (3) pasal ini, maka Pengurus Wilayah yang mencatat keanggotaan luar biasa yang bersangkutan dan berhak menerbitkan Surat Keterangan Anggota Luar Biasa (SKALB).

6. Terhitung sejak pencatatan keanggotaan luar biasa yang bersangkutan, Pengurus daerah menerbitkan Surat Keterangan Anggota Luar Biasa (SKALB) yang tembusannya disampaikan kepada Pengurus Wilayah. ${ }^{8}$

\footnotetext{
${ }^{8}$ Pasal 4 Perubahan Anggaran Rumah Tangga Ikatan Notaris Indonesia Hasil Rapat Pleno Pengurus Pusat Yang Diperluas (Pra Kongres Luar Biasa) Ikatan Notaris Indonesia, Pekanbaru, 7 Desember 2012
}

Sumpah atau janji dilakukan notaris sebelum menjalankan tugas jabatannya, mengandung dua hal yang harus kita pahami, yaitu :

1. Secara vertikal kita wajib bertanggung jawab kepada Tuhan, karena sumpah atau janji yang kita ucapkan berdasarkan agama kita masing-masing, dengan demikian artinya segala sesuatu yang kita lakukan/kerjakan akan diminta pertanggung jawabannya dalam bentuk yang dikehendaki Tuhan;

2. Secara horizontal kepada negara dan masyarakat, artinya Negara telah memberi kepercayaan kepada kita untuk menjalankan sebagian tugas negara dalam bidang hukum perdata, yaitu dalam pembuatan alat bukti berupa akta yang mempunyai kekuatan pembuktian yang sempurna, dan kepada masyarakat yang telah percaya bahwa Notaris mampu memformulasikan kehendaknya ke dalam bentuk akta Notaris, dan percaya bahwa Notaris mampu menyimpan (merahasiakan) segala keterangan atau ucapan yang diberikan dihadapan Notaris. ${ }^{9}$

\footnotetext{
${ }^{9}$ Habib Adjie, Op. Cit., h. 63-64
} 
2. Karateristik Akta Otentik

Terhadap hal-hal yang disampaikan kepada notaris, apakah itu mengandung suatu kebenaran atau tidak, hal tersebut bukanlah kewenangan notaris.Apabila akta notaris tersebut mengandung kebohongan atau kepalsuan dimana keterangan yang diberikan kepada notaris tidak benar maka tidak menjadikan akta tersebut sebagai akta palsu, sepanjang notaris tersebut tidak mengetahui bahwa keterangan yang diberikan kepadanya adalah tidak benar atau palsu.

Dari uraian tersebut di atas maka antara akta otentik yang dibuat "oleh" dan yang dibuat "dihadapan" pegawai umum terdapat perbedaan pokok antara lain :

1. Pada akta otentik yang dibuat "oleh" pegawai umum, inisiatif datang dari pihaknya, pihaknya mengetahui benar tentang hal-hal yang dikemukakan dalam akta (isi akta), sedangkan pada akta otentik yang dibuat "dihadapan" pegawai umum yaitu notaris, notaris tidak pernah memulai inisiatifnya, notaris tidak tahu benar kebenaran dari hal-hal yang dikemukakan oleh kedua belah pihak yang hadir dihadapannya (isi dari akta), ia hanya membantu merumuskan kehendak para pihak.

2. Akta otentik yang dibuat "dihadapan" pegawai umum biasanya disebut juga dengan akta para pihak, dalam hal ini notaris pasif artinya notaris menunggu sampai ia diperlukan oleh pihak lain untuk membuatkan akta. Jadi tidak ia dengan sendirinya tanpa dipanggil membuat akta.

3. Akta yang dibuat "oleh" pegawai umum terhadap ketiadaan tanda tangan tidak mengakibatkan akta tersebut kehilangan otensitasnya. Sebagai contoh dalam pembuatan berita acara rapat umum pemegang saham dalam perseroan terbatas, sering kali orang-orang yang hadir telah meninggalkan rapat sebelum akta itu ditandatangani, dan oleh notaris cukup hanya menerangkan dalam akta tersebut bahwa para pihak yang hadir telah meninggalkan rapat sebelum menandatangani akta itu dan akta itu tetap merupakan akta otentik. Pada akta yang dibuat "dihadapan" pejabat umum, keharusan adanya tanda tangan para pihak adalah untuk mempertahankan otensitasnya. Jika akta tersebut tidak ditandatangani maka akta tersebut harus diterangkan apa yang menjadi alasan tidak ditandatanganinya akta itu, misalnya para pihak atau salah satu pihak buta huruf atau tangannya lumpuh. Keterangan notaris mengenai hal tersebut adalah sebagai tanda tangan (surrogaat). 
Dengan demikian dalam akta partij penandatanganan oleh para pihak adalah merupakan suatu keharusan. ${ }^{10}$

Suatu akta yang dibuat oleh notaris dalam kedudukannya dapat menjadi akta otentik apabila memenuhi persyaratan yang ditentukan dalam Pasal 1868 KUHPerdata, yaitu :

1. Akta harus dibuat "oleh" atau "dihadapan" seseorang pejabat umum.

2. Akta itu harus dibuat dalam bentuk yang ditentukan oleh undang-undang.

3. Pejabat umum oleh atau dihadapan siapa akta itu dibuat, harus mempunyai kewenangan untuk membuat akta itu.

\section{Hak dan Kewajiban Calon Notaris}

Calon Notaris pada dasarnya bukan suatu jabatan tertentu melainkan suatu penyebutan terhadap seseorang yang telah lulus dalam program studi strata dua kenotariatan dan melakukan magang, sehingga mengenai hak dan kewajibannya belum tercakup secara menyeluruh dalam suatu peraturan perundang-undangan yang berlaku, namun hak dan kewajiban calon notaris tersebut diatur dalam suatu aturan organisasi yaitu Ikatan Notaris Indonesia

\footnotetext{
10 Teguh Samudera, Hukum Pembuktian dalam Acara Perdata, Alumni, Bandung, 1992, h. 42
}

yang lebih lanjut diuraikan dalam Anggaran Rumah Tangga Ikatan Notaris Indonesia yang dalam aturan tersebut tidak dijelaskan mengenai calon notaris, namun secara pengertian bisa disamakan dengan Anggota Luar Biasa, dalam Anggaran Rumah Tangga tersebut disebutkan bahwa hak dari Anggota Luar Biasa yang disebutkan pada Pasal 6 ayat (3) Anggaran Rumah Tangga Ikatan Notaris Indonesia yang menyatakan Anggota Luar Biasa berhak untuk :

a. Mengikuti semua kegiatan Perkumpulan.

b. Mengeluarkan pendapat dalam Kongres, Konferensi Wilayah dan Konferensi Daerah.

Selanjutnya hak dari Anggota Luar Biasa disebutkan dalam ayat (5) yang menyatakan bahwa selain hak-hak yang terurai dalam ayat (1), ayat (2) dan ayat (3), setiap anggota berhak juga untuk :

a. Mendapatkan perlindungan dari Perkumpulan, sejauh hal itu dapat dan patut diberikan berdasarkan ketentuan dalam Anggaran Dasar dan Anggaran Rumah Tangga Perkumpulan serta peraturan perundang-undangan yang berlaku.

b. Mendapatkan bantuan dan layanan dari perkumpulan guna memperoleh bahan atau dokumen mengenai 
peraturan perundang-undangan dan peraturan perkumpulan serta bahan atau dokumen lainnya yang mempunyai hubungan langsung maupun tidak langsung dengan jabatan Notaris, satu dan lain dengan memperhatikan tata cara yang berlaku dalam perkumpulan.

Hak-hak calon notaris sebagaimana telah diuraikan diatas merupakan hak-hak yang bisa dinikmati atau diperoleh hanya dari perkumpulan atau organisasi Notaris sepanjang calon notaris tersebut telah mendaftarkan dirinya dan tercatat sebagai Anggota Luar Biasa, dengan tidak adanya peraturan perundang-undangan yang mengatur tentang hak-hak calon notaris, maka Negara dalam hal ini tidak menjamin secara keseluruhan atas pemenuhan hak-hak dari calon notaris.

Dalam hal calon notaris yang melaksanakan magang di kantor notaris, mengenai hak-haknya selama magang tidak tertuang atau terurai dalam aturan manapun, baik peraturan perundang-undangan maupun aturan yang terdapat dalam perkumpulan atau organisasi Ikatan Notaris Indonesia, hal ini akan menimbulkan kekhawatiran bagi calon notaris karena tidak ada standarisasi dalam pemberian hak-hak bagi calon notaris yang sedang magang, segala bentuk kebijakan mengenai apa yang kantor notaris berikan kepada calon notaris yang sedang magang tersebut mutlak menjadi hak penuh kantor notaris tersebut, termasuk kebijakan mengenai ilmu yang diberikan maupun hal lain yang diperlukan bagi calon notaris yang sedang magang, karena tidak ada panduan secara pasti mengenai apa yang harus dipelajari selama melaksanakan magang dikantor notaris, meskipun ada kewajiban bagi Notaris untuk menerima magang sebagaimana pada Pasal 16 ayat (1) huruf $\mathrm{n}$ yang menyebutkan bahwa dalam menjalankan jabatannya, Notaris wajib menerima magang calon notaris.

4. Tanggung Jawab Hukum Calon Notaris Yang Sedang Magang Dalam Merahasiakan Suatu Akta.

Beberapa model tanggung jawab hukum adalah sebagai berikut: ${ }^{11}$

a. Tanggung jawab dengan unsur kesalahan (kesengajaan dan kelalaian) sebagaimanapun terdapat dalam pasal 1365 KUHPerdata, yaitu: "tiap-tiap perbuatan melanggar hukum, yang membawa kerugian kepada seorang lain, mewajibkan orang yang karena

\footnotetext{
${ }^{11}$ www.oocities.org/ilmuhukum/babii.doc diakses pada tanggal 03 Mei 2014, pukul 20.45
} 
salahnya menerbitkan kerugian itu, mengganti kerugian tersebut".

b. Tanggung jawab dengan unsur kesalahan khususnya kelalaian sebagaimana terdapat dalam pasal 1366 KUHPerdata yaitu: "setiap orang bertanggungjawab tidak saja untuk kerugian yang disebabkan perbuatannya, tetapi juga untuk kerugian yang disebabkan kelalaian atau kurang hati-hatinya.

c. Tanggung jawab mutlak (tanpa kesalahan) sebagaimana terdapat dalam pasal 1367 KUHPerdata yaitu:

(1)Seseorang tidak saja bertanggung jawab untuk kerugian yang disebabkan karena perbuatannya sendiri, tetapi juga untuk kerugian yang disebabkan karena perbuatan orang-orang yang menjadi tanggungannya atau disebabkan oleh barang-barang yang berada dibawah pengawasannya;

(2)Orang tua dan wali bertanggung jawab tentang kerugian, yang disebabkan oleh anak-anak belum dewasa, yang tinggal pada mereka dan terhadap siapa mereka melakukan kekuasaan orang tua dan wali;

(3)Majikan-majikan dan mereka yang mengangkat orang-orang lain untuk mewakili urusan-urusan mereka, adalah bertanggung jawab tentang kerugian yang diterbitkan oleh pelayan-pelayan

atau

bawahan-bawahan mereka di dalam melakukan pekerjaan untuk mana orang-orang ini dipakainya;

(4) Guru-guru sekolah dan kepala-kepala tukang bertanggung jawab tentang kerugian yang diterbitkan oleh murid-murid dan tukang-tukang mereka selama waktu orang-orang ini berada dibawah pengawasan mereka;

Kewajiban atau keharusan calon notaris yang sedang magang dalam hal merahasiakan akta selain didasari pada Pasal 16 A ayat (2) UUJN juga didasari pada alasan bahwa segala yang tertuang dalam akta notaris merupakan kehendak dan pernyataan para pihak dalam konteks kepentingan pribadi (keperdataan) yang bersifat rahasia pribadi dan kerahasiaan kepentingan sehingga calon notaris harus atau wajib merahasiakannya sebagai bentuk perwujudan perlindungan untuk menjaga kepentingan yang bersifat pribadi tersebut, dengan demikian maka akan tercipta keteraturan serta berjalannya norma-norma hukum sehingga akan terhindar dari potensi terjadinya konflik, namun apabila dilihat secara seksama dibeberapa peraturan perundang-undangan seperti Undang-Undang Keterbukaan 
Informasi Publik juncto Undang-Undang Kearsipan bahwa keharusan atau kewajiban menjaga rahasia tidak hanya menjadi beban bagi Notaris atau pun calon notaris yang sedang magang, namun juga menjadi kewajiban bagi setiap orang untuk menjaga rahasia akta.

Terhadap kerahasiaan akta yang dibocorkan, maka akta tersebut akan menjadi potensi timbulnya suatu masalah hukum karena dapat merugikan pihak-pihak yang terkait di dalam akta tersebut, hal yang demikian itu terhadap para pihak yang merasa dirugikan atas bocornya suatu rahasia akta yang mereka buat dihadapan notaris dapat menuntut secara hukum baik kepada notaris ataupun kepada pihak lain yang telah membocorkan rahasia akta yang mengakibatkan kerugian bagi mereka atas hal tersebut diatas.

\section{BENTUK-BENTUK SANKSI HUKUM TERHADAP CALON NOTARIS YANGSEDANG MAGANG YANG MEMBOCORKAN RAHASIA AKTA}

Sanksi merupakan alat pemaksa, selain hukuman juga untuk mentaati ketetapan yang ditentukan dalam peraturan atau perjanjian.Sanksi juga diartikan sebagai alat pemaksa sebagai hukuman jika tidak taat kepada perjanjian. Menurut Philipus M. Hadjon, sanksi merupakan alat kekuasaan yang bersifat hukum publik norma hukum administrasi. Dengan demikian unsur-unsur sanksi yaitu $:^{12}$

1. Sebagai alat kekuasaan.

2. Bersifat hukum publik.

3. Digunakan oleh negara.

4. Sebagai reaksi terhadap ketidakpatuhan.

Sanksi merupakan bagian penutup yang penting dari hukum, dan tiap aturan yang berlaku di Indonesia selalu ada sanksi pada bagian akhir hukum tersebut.Pencantuman sanksi dalam berbagai aturan hukum tersebut merupakan kewajiban yang harus dicantumkan dalam setiap aturan hukum.Ketidaktaatan atau pelanggaran terhadap suatu kewajiban yang tercantum dalam aturan hukum mengakibatkan terjadinya ketidakaturan yang sebenarnya tidak diinginkan oleh aturan hukum yang bersangkutan.Hal ini sesuai dengan fungsi hukum yang dipakai untuk penegakan hukum terhadap ketentuan-ketentuan yang biasanya berisi larangan atau yang diwajibkan.

Dengan demikian hakikat sanksi sebagai suatu pakasaan, juga untuk

${ }^{12}$ Habib Adjie, Op. Cit., h. 200 
memberikan penyadaran kepada pihak yang melanggarnya, bahwa suatu tindakan yang dilakukannya tidak sesuai dengan hukum yang berlaku. ${ }^{13}$ Adanya sanksi yang diberikan kepada siapa saja yang melanggar aturan maupun norma-norma yang ada, tentu akan menjadi kontrol terhadap kemungkinan adanya benturan kepentingan antar masyarakat, sehingga suatu negara dapat berjalan lebih teratur dan harmonis.

Hukum diciptakan untuk menjamin kepastian hukum karena bertujuan untuk ketertiban masyarakat.Dengan adanya kepastian hukum mengenai kewajiban calon notaris yang sedang magang untuk merahasiakan isi akta notaris tersebut maka tujuan dari Pasal 16 A ayat (2) dapat tercapai dan kepentingan masyarakat pun dapat terlindungi. Seorang yang mempunyai kewajiban menyimpan rahasia dapat dikenakan pidana sesuai dengan Pasal 322 KUHP apabila ia membocorkan rahasia yang dipercayakan kepadanya tersebut. Pasal 322 KUHP berbunyi :

“(1) Barangsiapa dengan sengaja membuka rahasia, yang menurut jabatannya atau pekerjaannya, baik yang sekarang maupun yang dahulu, ia diwajibkan menyimpannya, dihukum penjara selama-lamanya 9 (sembilan)

${ }^{13}$ Ibid., h. 201 bulan atau dendan sebanyak-banyaknya Rp.9.000,- (sembilan ribu rupiah).

(2) Jika kejahatan ini dilakukan terhadap seorang yang ditentukan, maka perbuatan itu hanya dituntut atas pengaduan orang itu."

Supaya dapat dihukum menurut pasal sebagaimana tersebut diatas, maka elemen-elemen yang harus dibuktikan adalah :

a. Yang diberitahukan (dibuka) itu harus suatu rahasia.

b. Bahwa orang itu diwajibkan untuk menyimpan rahasia tersebut dan ia harus benar-benar mengetahui, bahwa ia wajib menyimpan rahasia itu.

c. Bahwa kewajiban untuk menyimpan rahasia itu adalah akibat dari suatu jabatan atau pekerjaan yang sekarang, maupun yang dahulu pernah ia jabat.

d. Membuka rahasia itu dilakukan dengan sengaja.

Calon notaris yang sedang magang tidak dapat dikenai pidana dalam Pasal 322 KUHP apabila ia membocorkan rahasia. Sebab salah satu ketentuan bahwa seseorang dapat dipidana menurut pasal tersebut adalah kewajiban untuk menyimpan rahasia itu yang merupakan akibat dari suatu jabatan atau pekerjaan yang sekarang, maupun yang dahulu 
pernah ia jabat. Calon notaris yang sedang magang dalam kedudukannya tidak menjabat suatu jabatan tertentu atau pun pekerjaan seperti yang dimaksud dalam Pasal 322 KUHP tersebut, walaupun dalam Pasal 16 A ayat (2) UUJN ada kewajiban merahasiakan isi akta dan segala keterangan yang diperoleh guna pembuatan akta, namun dalam UUJN tidak dijelaskan sanksi terhadap pelanggaran atas pasal tersebut, karena pengertian jabatan sendiri menurut arti dalam kamus, bahwa jabatan berarti pekerjaan (tugas) dalam pemerintahan atau organisasi.

Apabila ditinjau dari teori kewajiban, maka yang dapat dikenai sanksi tidak semata-mata delik, tetapi juga yang memiliki hubungan hukum dengan delik. Kewajiban hukum adalah kewajiban untuk tidak melakukan perbuatan hukum yang dilarang atau kewajiban untuk memenuhi norma hukum. Kewajiban hukum adalah perbuatan dengan mana jika dilakukan berarti menghindari pelanggaran. Kewajiban untuk merahasiakan isi akta dan keterangan yang diperoleh dalam pembuatan akta, beradasarkan Pasal 4 ayat (2) dan Pasal 16 ayat (1) huruf e UUJN, hanya diperuntukkan bagi Notaris serta Pasal 16 A ayat (2) UUJN juga diperuntukkan bagi calon notaris yang sedang magang, namun bagi calon notaris yang sedang magang tidak dapat dikenakan Pasal 322 KUHP karena ia bukan seorang pemangku jabatan. Hukum dapat memerintahkan petugas untuk melaksanakan sanksi tertentu dalam kondisi tertentu terhadap calon notaris yang sedang magang yang tidak tdak merahasiakan isi akta dan segala keterangan yang diperoleh guna pembuatan akta.

Perbuatan membocorkan atau membuka rahasia isi akta yang dilakukan calon notaris yang sedang magang tersebut dapat dikatagorikan sebagai suatu perbuatan melawan hukum seperti yang tercantum dalam Pasal 1365 KUHPerdata karena bertentangan dengan asas kepatutan, ketelitian, serta sikap hati-hati yang seharusnya dimiliki seseorang. Eksistensi kewajiban hukum adalah semata-mata kepastian suatu norma hukum yang membuat sanksi tergantung kepada tindakan sebaliknya dari kewajiban hukum. Walaupun calon notaris yang sedang magang bukan suatu jabatan, namun ketika ia membocorkan isi akta, perbuatannya tersebut termasuk suatu perbuatan melawan hukum.

\section{PENUTUP}

\section{Kesimpulan}


1. Dengan konsep bahwa tanggung jawab merupakan pelaksanaan dari suatu kewajiban, maka bentuk tanggung jawab dari calon notaris yang sedang magang terhadap kerahasiaan akta, yaitu dengan melaksanakan kewajiban sebagaimana telah dinyatakan dalam Pasal 16A ayat (2) UUJN secara konsisten. Dengan terbitnya Pasal 16A ayat (2) UUJN tersebut, maka calon notaris yang sedang melaksanakan magang diberi tanggung jawab secara nyata oleh negara untuk merahasiakan hal-hal yang berkaitan dengan pembuatan akta, sehingga calon notaris dapat dikenai sanksi atas tidak dilaksanakannya kewajiban sebagaimana telah disebutkan dalam UUJN tanpa harus serta merta melibatkan kantor notaris tempat ia melaksanakan magang.

2. Bagi calon notaris yang sedang magang yang tidak melaksanakan kewajiban sebagaimana yang telah diamanahkan oleh UUJN Pasal 16A ayat (2), maka perbuatan calon notaris tersebut dapat dikenai sanksi pidana yang ancaman hukumannya tertuang dalam Pasal 85 Undang-Undang Nomor 43 Tahun 2009 Tentang Kearsipan juncto Pasal 54 ayat (1) Undang-Undang Nomor 14 Tahun 2008 Tentang Keterbukaan Informasi Publik. Tidak hanya sanksi pidana saja yang dapat diterapkan bagi calon notaris yang melanggar Pasal 16A ayat (2) UUJN, namun ada juga ancaman sanksi perdata, yaitu sebagaimana tertuang dalam dalam Pasal 1365 KUHPerdata, pengenaan sanksi pada pasal tersebut didasarkan bahwa calon notaris yang membocorkan rahasia akta telah melanggar hak-hak dan kepentingan subyektif dari para pihak yang ada didalam akta sehingga bisa menyebabkan timbulnya kerugian bagi para pihak.

\section{Saran}

Sebaiknya Organisasi Ikatan Notaris Indonesia mulai memikirkan formula yang tepat untuk standarisasi prosedur magang, yang didalamnya mengatur tentang hak dan kewajiban bagi calon notaris secara jelas, sehingga dengan demikian akan mengurangi kesalahan atau kekeliruan yang dilakukan calon notaris pada saat setelah menjadi notaris, Organisasi Ikatan Notaris Indonesia juga harus melakukan kontroling secara ketat terhadap proses magang ini, hal ini dilakukan untuk mencegah proses magang hanya menjadi formalitas belaka. Agar sanksi-sanksi yang telah diuraikan pada Bab III Tesis ini dapat dijalankan dengan baik dan maksimal, serta perlu adanya sanksi yang diberikan atau diatur secara tersendiri dalam organisasi notaris, sehingga bagi 
calon notaris atau pun bagi siapa saja yang melakukan pembocoran terhadap rahasia akta dapat lebih memiliki tanggung jawab untuk merahasiakan segala sesuatu tentang akta tersebut, sertameminimalisir permasalahan-permasalahan hukum yang berakibat pada timbulnya kerugian bagi para pihak yang terkait dengan akta tersebut.

\section{DAFTAR PUSTAKA}

\section{Buku-buku}

Abdulkadir Muhammad, Hukum Acara

Perdata Indonesia, Citra Aditya Bakti, 1992.

A. Pitlo, alih bahasa M. Isa. Arief, Pembuktian dan Daluwarsa Menurut Kitab Undang-Undang Hukum Perdata Belanda, Intermasa, Jakarta, 1978.

C.S.T Kansil dan Christine S. T. Kansil, Hukum Tata Negara Republik Indonesia, Rineka Cipta, Jakarta, 2008.

D. Schaffmeister, N. Keijer dan E. P. H. Sutorius, Hukum Pidana, Konsorsium Ilmu Hukum Departemen $\mathrm{P}$ dan $\mathrm{K}$, Yogyakarta, 2004.

G.H.S Lumban Tobing, Peraturan Jabatan Notaris, Erlangga, Jakarta, 1983.

Hans Kelsen, sebagaimana diterjemahkan oleh Raisul Mutaqien, Teori Hukum
Murni Dasar-Dasar Ilmu Hukum

Normatif, Nusa Media, Bandung, 2013.

Habib Adjie, Hukum Notaris

IndonesiaTafsir Tematik Terhadap UU

No. 30 Tahun 2004 Tentang Jabatan

Notaris, Refika Aditama, Bandung, 2008.

Kamisa, Kamus Besar Bahasa Indonesia, Cahaya Agency, Surabaya, 2013.

Khairunnisa, Kedudukan, Peran dan

Tanggung Jawab Hukum Direksi, Pasca

Sarjana, Medan, 2008

Komariah, Edisi Revisi Hukum

Perdata,Universitas Muhammadiyah

Malang, Malang, 2001.

Laden Marpaung, Unsur-Unsur Perbuatan

Yang Dapat Dihukum, Sinar Grafika, Jakarta, 1991.

M. Abdurachman, Hukum Acara Perdata, Universitas Trisaksi, Jakarta, 2008.

M.A. Moegni Djojodirdjo, Perbuatan Melawan Hukum : Tanggung Gugat (Aansprakelijkheid)

Untuk

Kerugian, Yang Disebabkan Karena

Perbuatan Melawan Hukum,

Pradnya Paramita, Jakarta, 1979.

Munir Fuady, Perbuatan Melawan Hukum, Pendekatan Kotemporer, Citra Aditya Bakti, Bandung, 2002.

Peter Mahmud Marzuki, Penelitian Hukum, Kencana Prenada Media Group, Jakarta, 2007. 
Purbacaraka, Perihal Kaedah Hukum, Citra Aditya, Bandung, 2010.

R. Tresna, Komentar HIR, Pramadnya Paramitha, Jakarta, 1993.

Teguh Samudera, Hukum Pembuktian dalam Acara Perdata, Alumni, Bandung, 1992.

Sjaifurrachman dan Habib Adjie, Aspek Penanggungjawaban Notaris dalam Pembuatan Akta, Mandar Maju, Bandung, 2011.

Soerjono Soekanto, Beberapa Masalah Hukum Dalam Kerangka Pembangunan di Indonesia (Suatu Tinjauan Secara Sosiologis), Universitas Indonesia, Jakarta, 1999.

Soejono dan H. Abdurahman, Metode Penelitian Hukum, Rineka Cipta, Jakarta,2003.

Subekti, Hukum Pembuktian, Pramadnya Paramitha, Jakarta, 2005.

Sudikno Mertokusumo, Hukum Acara Perdata Indonesia, Liberty, Yogyakarta, 2006

Supriadi, Etika \& Tanggung Jawab Profesi Hukum di Indonesia, Sinar Grafika, Jakarta, 2008.
Tan Thong Kie, Study Notariat Dan Serba-Serbi Praktek Notaris, Cet. 1, Ichtiar Baru van Hoeve, Jakarta, 2007.

Taufik Makarao, Pokok-pokok Hukum Acara Perdata, Rineka Cipta, Jakarta, 2004.

\section{Peraturan Perundang-Undangan}

Undang-Undang Nomor 2 Tahun 2014 Tentang Jabatan Notaris.

Undang-Undang Nomor 43 Tahun 2009 Tentang Kearsipan.

Undang-Undang Nomor 14 Tahun 2008

Tentang Keterbukaan Informasi Publik.

Kitab Undang-Undang Hukum Perdata.

Kitab Undang-Undang Hukum Pidana.

Staadblad Nomor 3 Tahun 1860.

\section{Lain-Lain}

Anggaran Rumah Tangga Ikatan Notaris Indonesia Hasil Rapat Pleno Pengurus Pusat Yang Diperluas (Pra Kongres Luar Biasa) Ikatan Notaris Indonesia, Pekanbaru, 7 Desember 2012.

www.wikipidie.com diakses pada tanggal 3 Mei 2014, pukul 20.15 WIB.

http://www.hukumonline.com/berita/baca/ hol20023/urgensi-magang-bagi-calon-n otaris, diakses pada tanggal 20 September 2014, pukul 20.00 WIBB. 